\title{
The New Economy: Reality and Policy
}

\author{
John Van Reenen ${ }^{1}$
}

June 2001

\begin{abstract}
This paper concerns the new economy (alias the knowledge-based economy). I examine the different meanings attached to the new economy term and the evidence surrounding it, concentrating on the upsurge in U.S. productivity growth between 1995 and 2000. I argue that the reports of the death of the new economy have been greatly exaggerated. There is evidence that information technology has transformed the U.S. economy and is this likely to have a strong impact on the U.K. economy in coming years. I discuss how elements of public policy should adapt to these economic changes both in terms of an overall framework and in applications to specific areas (technology policy, human capital policy, competition policy and industrial policy). The new economy is a place of hope and fear. The hope is that policy activism can cement in potential productivity gains; the fear is that government actions will not mitigate the ineluctable pressures towards social exclusion.
\end{abstract}

Keywords: knowledge, inequality, productivity, policy.

JEL Classification: O3, H1, J3

\section{Acknowledgements}

This is based on my inaugural lecture given in December $7^{\text {th }} 2000$ in the Department of Economics, University College London. I would like to thank David Card and Richard Blundell for comments, and my colleagues at UCL and IFS who have given me innumerable insights and valuable support over the years. Special thanks are also due to my father and Zvi Griliches. Their scholarly support and friendship are sorely missed.

\footnotetext{
${ }^{1}$ University College London and Institute for Fiscal Studies; jvanreenen@ifs.org.uk
} 


\section{Introduction}

\section{The New Economy is dead. Long live the New Economy!}

The new economy has gone from hero to zero in truly "Internet time". Less than a year ago it was trumpeted not only in breathless tones by WIRED, but also by the Chairman of the U.S. Federal Reserve Bank ${ }^{2}$ and even members of our own Monetary Policy Committee ${ }^{3}$. In mid 2001, newspapers are full of the "end of the new economy" in the face of a stalled U.S. economy, a devastated sector and plummeting profits of global high tech titans.

Some commentators have responded to these events by declaring the death of the new economy. Others have claimed that the speed of the downturn actually reflects the very nature of the new economy, where the business cycle peaks are much higher and the valleys far deeper ${ }^{4}$.

Both claims are premature. In this paper I probe hard into whether there really is something "new" in the economy. I will argue that there have been distinct glimmers in the United States but not (as of yet) in any other large economy ${ }^{5}$. Nevertheless, if we believe in some of the old rules of how technology is transferred across national boundaries then the immense productivity gains in the United States since 1995 promises future wealth in the U.K. and Europe. But this process of convergence is not automatic. I will argue that there needs to be some policy activism to reap the maximum benefits and to minimise the costs. These costs could be spiralling inequality and insecurity. Major technical changes provoke resistance from constituencies wider than just the followers of Captain Ludd. I describe a sequence of linked policies can speed up productivity growth and expand the "winner's circle" incentives for R\&D, expansion of basic human capital, an aggressive competition policy and a sector-specific industrial policy.

Economists and other social scientists have long been fascinated with the consequences of technology since the birth of the discipline ${ }^{6}$. This paper continues this traditional obsession with a modern twist.

The plan of the paper is as follows. Section II discusses what we mean by the "new economy", Section III examines the empirical evidence focusing on the recent productivity growth experience and section IV looks at inequality. Section V sets out a general policy framework and section VI examines some policies on R\&D, human

\footnotetext{
2 "This past decade has been extraordinary for the American economy and monetary policy. The synergies of key technologies markedly elevated prospective returns on high -tech investments, led to a surge in business capital spending and significantly increased the underlying growth rate of productivity" Alan Greenspan's report to the US Congress, February 13 2001. Full text available on www.ft.com/greenspantext

${ }^{3}$ For example, Wadhwani (2000)

${ }^{4}$ John Chambers, CEO of Cisco Systems.

${ }^{5}$ A case could be made for some smaller countries (e.g. Ireland and Finland), but I think there are special circumstances for these nations.

${ }^{6}$ For example, David Ricardo's (1911) chapter On Machinery in The Principals of Political Economy and Taxation; Adam Smith (1776) on the pin factory in the Wealth of Nations; Karl Marx (1859) on the primacy of the forces of production (Preface to the Critique of Political Economy)
} 
capital, product market competition and specific sectors ("industrial policy"). Some concluding comments are offered in section VII.

\section{What do people mean by the "New Economy"?}

Although the terms mean different things to different people (and I will use the terms new economy and knowledge economy interchangeably), all agree that the new economy it is characterised by the importance of information and communication technologies (ICTs). These include computer hardware, software, peripherals, as well as communications and related equipment. The internet is the latest platform built upon these ICTs. On the supply side, the fundamental driver of the growth of ICTs is the semi-conductor chip and the enormous falls in the quality-adjusted prices of these chips have lain behind the phenomenal escalation in the importance of the computer over the last three decades (see section III). The killer fact here is that the U.S. price index for semi-conductors has fallen from 10,000 in 1974 to 0.1 in 1999.

Many writers have a far broader notion of the "new economy" in mind than simply their technologies. Some of them argue that the economic principles that have guided policy- making, investment choices and empirical work in the past are largely redundant. A new age of global competition and rapid technological change has altered the ground rules. The Wall Street Journal, for example, offers the following: "When it comes to technology even the most bearish analysts agree the microchip and the internet are changing almost everything in the economy" (Ip, 2000)

\begin{tabular}{|l|l|}
\hline Table 1: Key Features of the new economy \\
\hline Feature & Definition \\
\hline Digital Revolution & $\begin{array}{l}\text { Prevalence of information and } \\
\text { communication technologies (ICTs), } \\
\text { especially computers }\end{array}$ \\
\hline Human Capital & Rapid growth of education and training \\
\hline Innovation & $\begin{array}{l}\text { R\&D, know-how, brands and other forms of } \\
\text { intangible capital more important than fixed } \\
\text { capital }\end{array}$ \\
\hline Mobility/globalisation & $\begin{array}{l}\text { capital (financial, fixed and highly skilled) } \\
\text { very mobile across national borders }\end{array}$ \\
\hline Entrepreneurial capacity & $\begin{array}{l}\text { Start-ups and new entrants key driver of } \\
\text { growth }\end{array}$ \\
\hline Clusters & $\begin{array}{l}\text { Geographical concentration of high tech } \\
\text { firms (e.g. Silicon Valley) }\end{array}$ \\
\hline Inequality & $\begin{array}{l}\text { Increasing wage dispersion and volatility of } \\
\text { income, "winner take all" in labour and } \\
\text { product markets }\end{array}$ \\
\hline Public/private & $\begin{array}{l}\text { A blurring of the divisions between the } \\
\text { public and private sectors }\end{array}$ \\
\hline
\end{tabular}


Table 1 offers some key features of the new economy. Many of these features are based on the importance of information. Information is a commodity very different from the standard goods and services analysed by economics texts. Although frequently costly to produce, information is hard to keep secret. It can be transmitted at low cost without reducing the pleasure of consumption to the person who first has the knowledge. The contrast between standard goods and knowledge is similar to that between cakes and recipes. A cake is costly to produce and rivalrous - if I eat it you cannot. Recipes on the other hand can be reproduced very easily and consumed by many people at the same time. The old economy specialised in manufacturing cakes whereas the new economy specialises in creating recipes. This could be seen as the movement away from the economics of Adam Smith towards the economics of Delia Smith (Leadbetter, 2000).

This poses an old dilemma. Since the research necessary to produce recipes is costly how does the inventor appropriate the benefits from this work when the information spills over so easily to others? ${ }^{7}$ Intellectual property (patents, copyrights, trademarks, etc) was invented to increase the ability of inventors to appropriate the benefits of their intellectual labour by granting them a temporary monopoly. The importance of such knowledge monopolies gives the new economy a "winner-take-all character". Yet monopoly power creates other problems and poses problems for anti-trust policy (I return to this in section VI).

Two further things are worth noting about Table 1. First, many of these features are not fundamentally driven by new technology. The increased mobility of capital was made possible as much by political agreements over the liberalisation of financial and other markets as anything else. Second, many of the features, such as the effect of innovation in gaining competitive advantage, have been around a long time.

Schumpeter and the Austrian economists have based a whole paradigm in economics based on the importance of innovation ${ }^{8}$.

Although the issues are not new, the fact that the sectors of the economy were knowledge is vital have been quantitatively expanding comes close to making the economy appear qualitatively different. The statistical weight of the "weightless" part of the economy has become significant. For example, in 1934 R\&D was about less than one half of one percent of net output, today it stands at over $5 \%$. Other indicators are the huge growth in the proportion of people with higher education, training and the escalation of advertising budgets ${ }^{9}$.

\footnotetext{
${ }^{7}$ As Flaubert lamented in his Dictionnaire des idées reçue. "Innovation - Always dangerous. Inventors - They all die in the hospice. Somebody else profits by their discoveries; it is not fair" ${ }^{8}$ Although it is true that Schumpeter has had a long-standing subterranean influence upon the economics profession, his full impact did not come until the development of endogenous growth theory. Part of this was due to Schumpeter's rather informal style. Lionel Robbins is reported to have characterised his major work Capitalism, Socialism and Democracy as a "supremely intelligent afterdinner talk"

${ }^{9}$ One may have expected the importance of brand name to decline and the importance of technical quality and price to increase. Bresnahan et al (1997) show that brand is as important as technical competence even in the personal computer industry. I show that the evidence on the importance of the internet in stimulating price competition is mixed in section III.3.
} 
Whichever position one takes on the new economy, broad or narrow, if there is something new we should be able to track it in our data. The strongest argument against the view that there is anything very new in the world's economy has always come from the productivity numbers. In the two decades following the oil price shock of 1973 there was a massive increase in computing power. Yet, in the United States, the world's leading economy, productivity growth was actually slower than it had been in the previous sixty years. Output per hour grew by about $1.9 \%$ per annum between 1913 and 1972 but by only 1\% per annum between 1972 and 1995 (Gordon, 2000).

What is going on? How, in the oft-quoted words of Robert Solow (1987), we could "see computers everywhere except for the productivity statistics"? Over the last six years in the United States many have claimed there is at last evidence of a step change in productivity. We now turn to this crucial evidence.

\section{The best evidence for the New Economy: the record on Productivity}

Productivity is the key quantum of economic health. Over the long run wages will reflect productivity growth, and consumption - the principal monetary measure of welfare - is mostly financed by wages (either past, present or future). Although there has been a lot of attention on low inflation, low unemployment and high stock market values as indicators of the new economy these are largely sideshows. Faster technical change should be reflected in a growth in increased output per hour. To economists, inflation is primarily a monetary phenomenon. Unemployment is largely independent of technical change in the longer run ${ }^{10}$. Looking over the last 200 years, despite a steady march of technology unemployment is largely untrended (Layard, Nickell and Jackman, 1991). The vigorous debate over whether the huge stock market values of the late Twentieth Century signalled the new economy or where driven by the froth of expectational bubbles has diminished as these same markets have tumbled. Yet even in the heady days of the first quarter of 2000 it was clear to most observers that there was massive over-valuation, even on the most optimistic assumptions ${ }^{11}$. Now that most dot.coms are dot.gones it is clear that there was massive over-valuation.

One direct measure of technological change is patenting activity. There is a hint in the US patent statistics of an upsurge in the 1990s. Between 1900 and 1985 the average number of patent applications by US inventors was 40,000 to 80,000 a year. In 1995, by contrast, 120,000 patents were applied for by US inventors. Although there could be other explanations for this surge this Kortum and Lerner (1998) persuasively argue that accelerating technical change is the most likely candidate ${ }^{12}$.

\footnotetext{
${ }^{10}$ In the short-run there can be an impact, of course (see Black and Lynch, 2001, for example). Even in the long-run the statement needs some qualification. It may be that the internet can reduce the level of structural unemployment, or NAIRU, by improving the job search and matching process in the labour market. There were 5000 job sites and web-based recruitment agencies in the US by the end of 2000 . Improved IT in public employment service may help. The C.V. of every unemployed person in Germany in available on the Web for employers to examine.

${ }^{11}$ For evidence on over-valuation see Shiller (2000) and Bond and Cummins (2000). For a perspective on rational valuation under conditions of great uncertainty see Hall (1999).

${ }^{12}$ The other major explanation is that the U.S. courts became more "patent friendly" following the establishment of the Courts of Appeals of the Federal Circuit by Congress in 1982. But this would imply that the US should have become a more favoured destination for patents from firms in all countries, not just the US based firms. In fact there appears to have been no major switch towards
} 
There are essentially two ways to measure productivity. The first is labour productivity that is simply real output (or value added) divided by labour services (hours worked). The second is multi (or total) factor productivity (MFP). This is output relative to all inputs (labour and non-labour). MFP is the usual way to measure disembodied technological change, as it is the residual left over when all other factors have been accounted for (Solow, 1957). But of course MFP represents (uncompensated) improved efficiency from all sources as well as a hefty dose of measurement error ${ }^{13}$. To put it crudely,

\begin{tabular}{|lll|}
\hline $\begin{array}{ll}\text { Labour Productivity Growth } \\
\text { (output per hour worked) }\end{array}$ & $=$ technical change & + Capital deepening \\
(MFP) & $+($ Growth of capital per hour $)$ \\
\hline
\end{tabular}

Fundamentally we care more about labour productivity, as this will have a direct effect on wages. Labour productivity can rise because of either a greater degree of inputs per person (e.g. more computer power per person hour) or an exogenous increase in technical change (MFP increases). From the perspectives of international technology transfer, however, it is MFP that is more important. A growth of MFP in the country at the edge of the technological frontier (e.g. the US) signals a potential for technology to spill over other countries further away from the leading edge (e.g. the UK). I discuss the implications of this in Section V.

\section{III.1 A Productivity miracle in the United States?}

In the U.S. labour productivity accelerated in the late 1990s relative to the previous twenty years by from just under $1.5 \%$ a year to just over $2.5 \%$. One percentage point is a substantial increase - worth about $\$ 92 \mathrm{bn}$ a year to the U.S. economy. There have been several recent attempts to examine the contribution of ICT ("computer capital deepening") and MFP ("pure technological change") to U.S. economic growth using the standard growth accounting framework. This decomposes overall economic growth into its constituent parts - inputs and $\mathrm{MFP}^{14}$. Table 2 (and Figure 1) are good examples of this approach. Taken from Jorgenson and Stiroh (2000) the last row illustrates the acceleration in productivity growth in the late 1990 s relative to the post 1973 trend $^{15}$.

\section{[Figure 1 about here]}

\footnotetext{
seeking protection in the US by foreign firms post 1982. The increase in patenting appears to be part of a worldwide increase, along with an improvement in the relative performance of US inventors.

${ }^{13}$ See Griliches (1996) for a historical account. He was always amused that economists specialising in technology placed maximum importance on an object that econometricians had always tried to minimise away - the residual.

${ }^{14}$ For example $y=m+b h+(1-b) k$ where $y$ is the rate of growth of output, $m$ is the growth rate of multi-factor productivity, $h$ is the growth rate of hours and $b$ is the elasticity of output with respect to hours (proxied by the share of labour in total output). We have assumed constant returns to scale. Rearranging labour productivity growth, $(y-h)=m+(1-b)(k-h)$ : a weighted sum of the growth of MFP and capital deepening.

${ }^{15}$ It is conventional to drop 1990-95 as this contained a deep recession, so the two periods 1973-90 and 1995-99 are more cyclically comparable. If the early 1990s were included in the baseline the acceleration in 1995-99 looks slightly larger.
} 
Table 2 Contributions to Output Growth

\section{(U.S. Non-Farm Non- Government business Sector Annual rates of change (percentage points))}

\begin{tabular}{|c|c|c|c|c|}
\hline & Category & $\begin{array}{l}\text { (1) 1974- } \\
90\end{array}$ & (2) 1995-99 & $\begin{array}{l}\text { Acceleration } \\
(2)-(1)\end{array}$ \\
\hline 1 & Growth of output & 3.13 & 4.76 & 1.63 \\
\hline 2 & Capital services $^{b}$ & 1.62 & 2.34 & 0.72 \\
\hline 3 & of which: $\mathrm{ICT}^{\mathrm{a}}$ & 0.37 & 1.01 & 0.64 \\
\hline 4 & $\begin{array}{ll}\text { capital } & \text { other } \\
\end{array}$ & 1.25 & 1.33 & 0.08 \\
\hline 5 & Labour Services & 1.17 & 1.44 & 0.27 \\
\hline 6 & of which: hours & 0.97 & 1.19 & 0.22 \\
\hline 7 & $\begin{array}{ll}\text { labour } \\
\text { quality }\end{array}$ & 0.2 & 0.25 & 0.05 \\
\hline 8 & $\begin{array}{l}\text { Multi-factor } \\
\text { productivity } \\
(\mathrm{MFP})\end{array}$ & 0.33 & 0.99 & 0.66 \\
\hline 9 & $\begin{array}{l}\text { Average Labour } \\
\text { Productivity } \\
\text { (ALP) }\end{array}$ & 1.44 & 2.56 & 1.12 \\
\hline
\end{tabular}

Source: Derived from Jorgenson and Stiroh (2000) Table 2

a. Includes services of consumer computers and software but not consumer communications equipment

b. Includes services of consumer durables

What accounted for the acceleration in overall economic growth (first row of Table 2) at the end of the 1990 s? Of the $1.63 \%$ acceleration $0.27 \%$ was simply due to a greater quantity and quality of labour (row 5). Labour inputs have increased mainly due to Welfare to Work reforms $\left({ }^{16}\right)$, immigration and the long economic boom. The remaining growth is accounted for by capital deepening in the use of ICTs $(0.64 \%$, row 3$)$ and MFP $(0.66 \%$, row 8$)$. Although the growth of the non-computer capital stock makes a larger contribution to overall economic growth (row 4), it made as large a contribution in the 1973-90 period as the 1995-99 period. ICT investment, although smaller in absolute terms, is responsible for a much larger part of the acceleration in growth at the end of the 1990s.

Although other authors using the growth accounting framework differ in details, they also find qualitatively similar results ${ }^{17}$. For example, Oliner and Sichel (2000) and Council of Economic Advisors (2000) both attribute the vast bulk of the acceleration in growth to MFP and ICT investment.

\footnotetext{
${ }^{16}$ For example time-limited benefits were introduced under the 1996 Personal Responsibility and Work Opportunity Reconciliation Act. See Blank and Card (2000) for an extensive discussion of the likely impact of this reform.

${ }^{17}$ We have presented the results up to 1990 rather than 1995 to avoid a potentially misleading comparison with the early 1990 s recession. This makes very little difference.
} 
It is not difficult to explain why there has been such rapid investment in ICT. The quality-adjusted price of computers fell 17.1 percent a year 1959 through 1995, but by 32.1\% percent per year between 1995 and 1998 (see Figure 2). As economic theory would predict, as their price fell computers have grown rapidly as a share of all investment and this growth accelerated in the late 1990s. Underlying these changes is Moore's Law: the number of transistors that can be crammed on a silicon chip has roughly doubled every 18-24 months. For example, the first logic chip/microprocessor released in 1971, the Intel 4004, could hold 2,300 transistors whereas the Pentium IV (released on November $20^{\text {th }} 2000$ ) could hold the equivalent of 42 million transistors. Since 1994 this cycle seems to have speeded up due to technological and competitive factors in the production of chips. Scientists expect this to hold good for at least the next 10-20 years (Jorgenson, 2001).

\section{[Figure 2 about here]}

So far so good for the new economy camp. Gordon (2000), however, delivers a much more sceptical interpretation of these figures. He makes two key points regarding the cycle and the contribution of the computer producing sectors. Firstly, he argues that some of the late 1990s change in productivity growth is caused by purely cyclical factors. It is well known that labour productivity growth is pro-cyclical and the US economy at the end of the 1990s, he argues, was growing way above its long-term trend. Table 3 shows the effect of making a cyclical adjustment to productivity is to downgrade the acceleration by about half a percentage point (row 3). Thus, the structural acceleration in labour productivity is only $0.64 \%$ (row 5). Secondly, he decomposes growth into different industrial sectors. MFP growth in the computermanufacturing sector was very substantial over this period. In fact it accounts for all of the structural acceleration in MFP over this period.

Gordon's conclusions are very striking. He argues that there has been no structural trend increase in labour productivity outside of the durable manufacturing industries (column 2 ) that only comprise $15 \%$ of the US economy. In fact, there has actually been a deceleration in MFP in $85 \%$ of the US economy. Thus, he concludes, for most of the economy the Solow paradox is alive and well. There does not appear to have been much of an effect of computer investment on productivity in large swathes of the economy.

The cyclical correction that Gordon attempts is open to criticism. The U.S. experienced an unprecedented period of continuous economic growth in the business cycle beginning in the early 1990s. The cyclical benefits of productivity growth would normally be exhausted at such a late stage of the cycle (1999). It is generally accepted, however, that the bulk of measured MFP increases have been heavily concentrated in the computer producing sectors. There could be several reasons why productivity growth has been disappointing outside durable manufacturing. 
Table 3 Decomposition of Growth in output per hour, 1995:4-1999:4 into contributions of cyclical effects and structural changes in trend growth. (percentage point growth at annual rate)

\begin{tabular}{|l|l|r|r|}
\hline & Item & $\begin{array}{l}\text { NFPB (Non Farm } \\
\text { Private Business) }\end{array}$ & $\begin{array}{l}\text { NFPB excluding } \\
\text { durable } \\
\text { manufacturing }\end{array}$ \\
\hline 1 & Actual growth & 2.75 & 1.99 \\
\hline 2 & $\begin{array}{l}\text { Contribution of } \\
\text { cyclical effects }\end{array}$ & 0.50 & 0.63 \\
\hline 3 & $\begin{array}{l}\text { Trend (1972:2- } \\
1995: 4)\end{array}$ & 1.42 & 1.13 \\
\hline 4 & Other factors & 0.19 & 0.19 \\
\hline 5 & $\begin{array}{l}\text { Structural } \\
\text { acceleration ( } \\
\text { row1-row2 - row 3 } \\
\text { row 4) }\end{array}$ & & \\
\hline 6 & capital deepening & 0.64 & 0.04 \\
\hline 7 & MFP in computers & 0.33 & 0.33 \\
\hline 8 & $\begin{array}{l}\text { structural growth in } \\
\text { MFP }\end{array}$ & 0.29 & - \\
\hline
\end{tabular}

Source: Gordon (2000)

a. "Other" includes the contribution of changes in price measurement and labour composition

1. Diminishing Returns. Gordon's preferred argument is that the marginal benefit of bytes has gone down fast due to the rapid expansion in the usage of computer power. The price declines of computers have been more rapid than previous innovations. The largest returns were to be had in the 1960s and 1970s with such things as the replacement of manual typewriters with word processors.

2. Learning. David (1990) has argued that, like the electric dynamo, it takes a generation to effectively learn how to make best use of computers. For example, new forms of organization (decentralisation, team working, delayering of middle managers) may be complementary to ICTs but difficult to implement. ${ }^{18}$ This argument may have seemed plausible fifteen years ago, but this appears less plausible as time goes on. One version of this "its still to come" argument is that business to business ("B2B") electronic commerce will finally delivery the productivity goods. We examine this below in section III.3.

3. Measurement. Real output is very hard to measure outside manufacturing industries (Griliches, 1994). Some of the largest computer using sectors (e.g. Finance,

\footnotetext{
${ }^{18}$ This is because of genuine uncertainty about whether the organisational changes will work, the need to introduce many of the changes as a large package of reforms and the resistence from incumobants who will be displaced by these new methods. See Bresnahan et al (2001) and Caroli and Van Reenen (2001) for micro-econometric evidence in the U.S., France and the U.K.
} 
retail and insurance) have unbelievably low or even negative productivity growth according to the official figures. Alternative methodologies of accounting for productivity growth do not find such a concentration in the ICT producing sector (e.g. Nordaus, 2001). A second line of attack is that the whole aggregate growth accounting method is flawed due to serious aggregation biases. Econometric work at the firm level tends to uncover much larger effects from the use of information technology on company productivity (see the survey in Brynjolfsson and Hitt, 2000, for example).

Gordon's work certainly forces us to put caveats around the U.S. "productivity miracle". Recent news seems to bear out his scepticism. Productivity growth in the first quarter of 2001 fell by $0.1 \%$. Semi-conductor prices fell by only $16 \%$ between April 2000 and March 2001 compared to $25 \%$ per annum in the previous five years. But we should not be misled by one quarter or even one year's figures. The rigorous research reported in this section uses data up to the end of 1999. 2000 was, on the whole, another strong year for U.S. productivity growth. In preliminary work, Sichel (2001) uses data through the fourth quarter of 2000 and finds a larger acceleration in labour productivity growth (1.24\% acceleration between 1996-2000 compared to $1.04 \%$ between 1996-1999 as reported in Oliner and Sichel, 2000). Despite the expectation of a fall in IT investments after 1999 when there had been big IT investments in preparation for the Millennium Bug, ICT investment rates actually rose. Clearly the next few years will be the real test for whether the increase in productivity is structural or cyclical. Only the foolish believed that the new economy had vanquished the business cycle. Taking the period since 1995 as a whole, I conclude there does seem to be some tangible evidence of an increase in productivity in the world's largest economy. But what of the rest of the world?

\section{III.2 Evidence on productivity in the U.K and Europe: No Miracle here}

European and Japanese productivity growth since 1945 has generally been faster than U.S. growth (see Table 4). This is primarily because non-US countries emerged from World War Two with lower levels of productivity and therefore more room to "catch up". This convergence occurred pretty evenly since 1950 . There was a worldwide slowdown in productivity growth after the oil shocks of the early 1970s. This slowdown was less dramatic in the U.K. than elsewhere, primarily because of improvements in productivity in the 1980s. These improvements were likely to be due to increases in competition (in product and labour markets) under Mrs Thatcher's reforms. In retrospect the reductions in union power, privatisation, deregulation and the withdrawal of subsidies for "lame duck" industries look like one-off gains in efficiency rather than increases in the rate of innovation ${ }^{19}$.

It is well known that the level of British labour productivity is lower than that of our major competitors. It is a major policy priority of Chancellor Gordon Brown to close

\footnotetext{
${ }^{19}$ For a discussion of the impact of the Thatcher administration on productivity see the contributions to Card and Freeman (2001). Unions are interesting example. Their influence has dramatically waned $53 \%$ of workers were in unions in 1980 compared to under $30 \%$ today. It is likely that unions reduced the level of productivity in the UK in the 1970s (Pencavel, 2001) but the evidence does not suggest they reduced the rate of innovation (e.g. Menezes-Filho, Ulph and Van Reenen, 1998).
} 
this productivity gap ${ }^{20}$. Table 5 shows the figures. Much of the gap between the UK and France/Germany can be accounted for by lower investment in fixed capital. This lower investment is mainly due to lower public spending on infrastructure and lower investment in the housing stock (see Bond and Jenkinson, 1998). The rest of the gap is accounted for by lower spending on skills. Nevertheless, even after accounting for these inputs a substantial gap (16\%) remained between Britain and the US in terms of TFP.

\section{[Figure 3 about here]}

The picture of recent productivity growth outside the US is disappointing. There has not been an acceleration in productivity growth in the late 1990s in any of the main economies outside of the USA. The UK position is illustrated in Figure 3. Why was the UK productivity growth in the late 1990s disappointing? The slowdown was concentrated in manufacturing where Sterling's strength hit hardest. There has also been an improvement in the employment rates for less skilled workers due to the sustained level of growth and welfare to work policies ${ }^{21}-$ this will tend to reduce measured productivity. But the U.S. has also been successful at increasing the employment of the less skilled through its own welfare to work policies, so the widening US-UK productivity gap cannot be explained by labour market policies.

\section{Table 4 Longer Productivity Growth Rates in Britain and other countries}

\begin{tabular}{|l|l|l|l|l|}
\hline & \multicolumn{2}{|l|}{ GDP per hour worked } & \multicolumn{2}{l|}{ Total Factor Productivity } \\
\hline & $1950-73$ & $1973-99$ & $1950-73$ & $1973-99$ \\
\hline UK & 2.99 & 2.11 & 1.69 & 1.55 \\
\hline France & 4.62 & 2.57 & 3.03 & 1.61 \\
\hline Germany & 5.18 & 2.39 & 3.73 & 1.70 \\
\hline US & 2.34 & 1 & 1.46 & 1.12 \\
\hline Japan & 6.11 & 2.78 & 3.39 & 0.66 \\
\hline
\end{tabular}

Source: O’Mahony (1999), Crafts and O’Mahony (2001)

\footnotetext{
${ }^{20}$ For a recent statement of government analysis and policy see HM Treasury (2000) and for a critical discussion see Griffith and Simpson, 1998.

${ }^{21}$ For evidence on the effectiveness of the New Deal in stimulating employment see Van Reenen (2001)
} 
Table 5 Levels of Productivity in 1999

\begin{tabular}{|l|l|l|l|l|l|}
\hline & UK & France & Germany & US & Japan \\
\hline $\begin{array}{l}\text { GDP per } \\
\text { capita }\end{array}$ & 100 & 106 & 112 & 142 & 105 \\
\hline $\begin{array}{l}\text { GDP per } \\
\text { hour }\end{array}$ & 100 & 133 & 128 & 126 & 88 \\
\hline $\begin{array}{l}\text { MFP, } \\
\text { market } \\
\text { sector }\end{array}$ & 100 & 121 & 112 & 118 & 77 \\
\hline
\end{tabular}

Source: Crafts and O'Mahony (2001). They refer to MFP as JFP, i.e. correcting for physical capital but not human capital or R\&D capital.

Is the relatively poor performance in the UK due to a lower investment in information and communication technologies than in the US? Unfortunately it is very difficult to clearly answer this question due to the poor quality of statistics on the UK ICT base. There is no official series measuring gross fixed investment in computer or ICT equipment, nor is there a rigorous quality adjusted price series.

Recent attempts to estimate the level and growth of ICT capital in the UK have used the US hedonic price deflator and spliced together a UK series of computer investment from the input-output tables. Figure 4 illustrated one attempt comparing the US with the UK and "Euroland" (the countries using the Euro). The unadjusted series show that Britain had just over 1\% productivity growth in the late $1990 \mathrm{~s}$ compared to $2 \%$ in Europe and 3\% in the US. Using the adjusted deflators, the UK improves, productivity growth rates appear similar to those in the rest of Europe. There remains, however, a sizeable gap with the US.

Kneller and Young (2000) find that the growth in the UK computer stock since 1979 was broadly comparable to that in the US. However, the share of the computer stock in GDP is much lower in the U.K. Oulton (2001) estimates that that ICT stock was $3.7 \%$ of GDP in the UK compared to $6.3 \%$ of GDP in the US. Thus the overall contribution of ICT to productivity growth was also much lower in the UK.

The conclusion appears to be that the lower level of the ICT stock partially explains the slower productivity growth in the UK than in the US in the late 1990s and the TFP gap with the USA ${ }^{22}$. But the vast majority of the difference is due to a higher rate of technical change (MFP) in the US than in the UK.

\section{III.3 A Digression: But what about the Internet?}

The potential productivity benefits of the Internet have been extensively discussed in the media and popular press. The late 1990s productivity boom in the US coincides with the spread of the Internet. By the end of 2000 about 50\% of Americans and a

\footnotetext{
${ }^{22}$ Crafts and O'Mahony (2001) estimate that only 1 percentage point of the $18 \%$ UK-US TFP gap can be accounted for by lower ICT stocks.
} 
third of the British were hooked up to the World Wide Web. This is the fastest rate of diffusion of a new technology since television began in the 1940s and 1950s. Internet based companies enjoyed extra-ordinarily high share values (until the corrections starting midway through the year 2000). Finally, the US leads the world in the density of Internet hosts (see figure 5). Is the Internet the "smoking gun"? ${ }^{23}$

\section{[Figure 5 about here]}

There are two channels that may cause the Internet to push down prices. Firstly, there are large potential savings in distribution costs - less rent, fewer staff, less packaging and middlemen, etc. Some estimates put the distribution cost as $30 \%$ of the final sales price of a car, for example. Secondly, downward pressure on prices may come from lower search costs as consumers can more easily compare prices from different web sites either via search engines or through on-line companies that generate price comparisons (i.e. "shopping bots" like MySimon). On the other hand, by using more information on consumers, retailers may be able to price discriminate more effectively (think of airline ticketing) and this could actually lead to higher prices for some groups.

There is a small but growing literature on the effects of the Internet on consumer prices. The evidence is mixed. Analysing on-line prices, Brynjolffson and Smith (2000) find that books and CDs tend to be about 9-16\% cheaper on-line compared to conventional retailers, even after shipping and handling costs. But Bailey (1998) found the opposite - in 1997 books, CD and software were more expensive on-line. Lee (1997) also found that cars were actually more expensive on-line than off-line.

Turning to the effects from online to offline Brown and Goolsbee (2000) found evidence of downward price pressure from internet-based life insurers on life insurance premiums offered in conventional ways. They concludes this rather indirectly by finding that groups who are more likely to use the internet are increasingly likely to be offered cheaper insurance rates.

If the Internet is transforming the economy then this should show up in the aggregate productivity figures. Since most internet-related activity would fall outside durable manufacturing it is open to the Gordon critique discussed in section III.2 above. He argues that the Internet stacks up badly relative to the great inventions of the late $19^{\text {th }}$ Century because (i) it mainly involves new delivery systems (duplicating mail order catalogues) rather than new products. The innovations of the early Twentieth Century were more radical - electric television, the telephone, cars and movies; (ii ) much of e-commerce is in defence of market share; (iii) much internet activity is actually workers enjoying more on the job consumption.

Larger productivity effects may come from business to business e-commerce (B2B) such as internet-based auctions of semi-conductor chips and the auctioning of surplus capacity when transporting goods. These activities are predicted to grow rapidly over the next few years ${ }^{24}$. Brookes and Wahhaj (2000) simulate a macro model building in

\footnotetext{
${ }^{23}$ See the collection of essays in the Winter 2001 Journal of Economic Perspectives for a longer discussion of the economics of the internet.

${ }^{24}$ Wadhwani (2000) reports from a Bank of England survey showing that while only $28 \%$ of UK businesses currently use the internet for purchases $68 \%$ expect to do so by the end of 2002 .
} 
analysts' forecasts of the reductions in the cost of intermediate goods. They claim that B2B should boost GDP growth by $0.25 \%$ a year for 10 years in the major industrialised nations. Unfortunately, it is hard to know how realistic these analysts' forecasts of costs savings are likely to be. There is an in-built tendency towards overoptimistic forecasts in many companies and this will be especially so in an area surrounded with so much uncertainty.

I conclude that the Internet has had, so far, a limited impact on productivity growth. It certainly cannot explain the macro-productivity findings.

\section{The upwards march of inequality}

So far we have concentrated on the impact of the new economy on the growth of economic wealth - but what about its distribution? One of the major topics of research in the last ten years has centred around the remarkable increase in wage inequality in the US and the UK and, to a lesser extent, many other OECD countries ${ }^{25}$. This is illustrated in Figure 6 that shows the change in wages at the $10^{\text {th }}, 50^{\text {th }}$ and $90^{\text {th }}$ decile of the hourly wage distribution for men. Inequality has grown rapidly since 1979 . The shift in inequality in the 1980s occurred in both Britain and America, although unlike the US there have not been falls in real wages for the lowest decile in the $\mathrm{UK}^{26}$. Part of this general increase in inequality has been caused by the increase in the rate of return to skill. For example the U.S. wage premium for an individual gaining a college degree (relative to a high school diploma) was 10\% for 26-30 year old in 1976. By 1996 the same 26-30 year old had a college wage premium of $35 \%$. In Britain the rate of return to college rose from $17 \%$ to $31 \%$ (see Card and Lemieux, 2000).

\section{[Figure 6 about here]}

There is a consensus that technical change has had some role to play in the decline in the demand for less skilled workers. There is now a large body of evidence that recent technology has been skill biased. Educated individuals find it easier to cope with the uncertainty surrounding the best use of new technologies, such as computers. ${ }^{27}$ Machin and Van Reenen (1998) for example, show that in seven OECD countries the industries that have had the fastest shakeouts in less skilled workers are the high tech industries (measured either by R\&D intensity or computer usage). These tend to be the same industries across different countries.

The presence of skill biased technical change cannot explain the increase in the relative wage of more skilled workers as technical change has been occurring for many years. Either it accelerated (as may have happened in the late 1990s) or something else also happened. Card and Lemieux (2000) emphasis a slowdown in the growth of the supply of education by cohort, Gosling and Machin (1995) emphasis labour market institutions (such as unions and the minimum wage) and Wood (1994),

\footnotetext{
${ }^{25}$ European countries have suffered from employment inequality -a large fall in the job prospects of less skilled individuals.

${ }^{26}$ Another difference is that although the wage gap between educated and less educated workers fell in the 1970s in the UK and in the US, within educational group inequality was rising throughout the 1970 s in the US whereas it was not in the UK.

${ }^{27}$ See Chennells and Van Reenen (2001) for a survey.
} 
amongst others emphasises trade. I am personally quite sceptical about the trade element ${ }^{28}$ but suspect that the first elements do have a role to play in addition to technology. The key issue, however, is that there is an underlying pressure to increase the demand for more skilled workers that is unlikely to recede. The quantity and quality of the supply of human capital is always playing catch-up with the demand side and there will be a tendency towards inequality between skill groups in the new economy.

The increase in cross sectional inequality can be decomposed into two parts. There is a "permanent" increase due to the higher rate of return to human capital. But there is also a "transitory" element related to the increase in volatility of income over the lifecycle. Blundell and Preston (1998) emphasis the importance of this second element by examining differences in the time series pattern of consumption and income by cohort and education group. This increased volatility of household's income may be a reason for the insecurity people feel in the modern economy. There does not seem robust evidence of a decrease in job tenures or job turnovers but survey evidence does point to a feeling of insecurity. Nickell et al (2000) have also shown that there has been an increase in the number of wage falls, especially for those in middle- income groups.

Policy-makers have recently become concerned by the "digital divide" - the fact that higher income people are more likely to have access to computers than lower income people $^{29}$. The policy response has been to attempt to make it easier for lower income people to have access to computers. This gets the causality entirely backwards. More recent technologies will always be purchased by wealthier people simply because they have more disposable income. Furthermore, giving a random individual a computer either at home or in the workplace will not automatically raise their wages. Highly skilled people get higher wages and are given access to new technologies because of their skills ${ }^{30}$. The correct policy response is to give people more skills, not more computer hardware.

The pressures towards greater inequality through skill biased technical change and through increased volatility are real enough. The increased inequality of wages accounts for the increased amount of inequality since 1997 despite the redistributive effects of the Chancellor's budgets (e.g. Working Family Tax Credit). The policy challenge is how to reap the productivity gains from the new economy without leaving behind those who will lose out.

\footnotetext{
${ }^{28}$ Desjonqueres, Machin and Van Reenen (1999) show that the industries experiencing the fastest shakeouts of unskilled workers across countries were not those with the greatest exposure to trade, from less developed countries or otherwise.

${ }^{29}$ For example, Department of Trade and Industry (2000)

${ }^{30}$ The positive correlation between wage and computer use highlighted by several authors (e.g. Krueger, 1994) is primarily due to the fact that high-wage workers are selected to use new technologies (see Chennells and Van Reenen, 1997, 2001).
} 


\section{A Policy Framework}

In this section I discuss a simple general framework for thinking about the effects of different policies in the new economy and in the next section I deal with some specific policy areas. Space limitations means that I cannot deal with many other issues such as the role of ICTs in improving the productivity of government or the impact of the internet on general tax policy.

The productivity growth tournament between countries is a strange race. Like the Mad Hatters' tea party “all will have prizes!”. In other words, every country can win from a structural speed up of U.S. productivity growth as the technological benefits spillover to other nations. The critical issue is how fast can the technology be transferred from the U.S. to other countries.

The current policy framework correctly identifies productivity as a key area for concern (HMT, 2000). Increases in investment are sought through greater macroeconomic stability and higher public investment. If successful these raise inputs per person, but are unlikely to raise MFP.

In Griffith, Redding and Van Reenen (2000) we propose a framework for analysing technical change in OECD countries ${ }^{31}$. For a sector in a country there is a equilibrium growth rate of MFP. In the long run this will depend on the rate of growth of MFP in the frontier country (often, but not always the USA). The level of MFP, however, will not necessarily be the same as that of the frontier country, even in the long run. Relative TFP levels will depend on exogenous factors outside a policy maker's influence (geography, culture) and endogenous factors that can be influenced by policy choices. We discuss some of these policy-sensitive factors below.

Within the OECD over the long haul, there is a tendency for those further behind to catch up with the leaders. This is the familiar process of convergence: the further you are behind the faster you catch up. But the $\$ 100 \mathrm{bn}$ question is: what are the factors that enable countries to catch up more quickly than others?

In fact, many of the variables that affect the long-run relative level of TFP will also affect the process of catch-up. Take R\&D, for example. Many writers have long claimed that it has "two faces" 32 . The familiar face is the way in which R\&D can stimulate innovation and push the technological frontier outwards. The less studied face is the role R\&D plays in helping firms learn where the current technological frontier actually is. A firm will need to have well trained scientists to read and understand leading edge scientific papers and patents in order to improve productivity. As a researcher I am often painfully aware of how much of my own research time is spent just understanding what other people have already accomplished rather than pushing forwards the boundaries of knowledge myself. Since most empirical studies of the rate of return to R\&D have focused on the U.S. this literature has underestimated the impact of $R \& D$. The impact of $R \& D$ on

\footnotetext{
${ }^{31}$ It is based on an endogenous growth model in the spirit of Aghion and Howitt (1998).

${ }^{32}$ For example, Cohen and Levinthal (1989)
} 
productivity is greater for countries further from the frontier who can use their $R \& D$ commitments both to innovate and to catch up.

Another factor that may generate innovation and learning are investments in human capital $^{33}$ - this has been the focus of endogenous growth theory. Empirical investigations have convincingly demonstrated the importance of the level of human capital in increasing the level of productivity, although the impact of the level of education on growth and convergence is more controversial ${ }^{34}$.

Trade is the third most commonly examined factor. Lower barriers to trade through tariff and quota reductions could stimulate productivity growth in a number of ways. First, it may be that capital imports from high tech countries embody the latest scientific knowledge. Secondly, openness may increase product market competition and therefore stimulate more innovation (see section VI.3). Of course there are also other ways to increase product market competition through better regulation, tougher competition policy and removal of government subsidies for failing firms.

Griffith et al (2000) produce strong evidence that human capital (as proxied by the proportion of workers in the country with college education) and R\&D stimulate both innovation and learning. The effects of trade are positive, but weaker than R\&D and skills $^{35}$. In thinking through policies to stimulate MFP growth, these are the factors we need to focus on.

\section{Specific Policies}

\section{VI.1 Innovation Policy: tax credits for R\&D}

$R \& D$ is only one part of the innovative process, but it is a very important part. Section II described how the effects of knowledge spilled over to other firms. This will generally imply an under-investment in $\mathrm{R} \& \mathrm{D}$ and therefore a need for more public support. The UK performance in R\&D has deteriorated since early 1980s. Part of this is due to the decline in government funding, but the picture is similar even if one looks at the industry-funded business performed part of R\&D (see Van Reenen, 1997)

Neither is the relative decline simply due to de-industrialization - such as a decline of particular high tech industries (e.g. the British computer industry). The stagnation of R\&D intensity is a general pattern within industries. Part of the reason could be linked to the failure to introduce a more favourable fiscal regime for R\&D as many other countries have introduced more generous fiscal provisions. Bloom et al (2001) show that $R \& D$ tax credits are quite effective at raising $R \& D$ over the long run. Griffith et al (2001) also examine evidence on the desirability of R\&D tax credits - by how much is TFP and growth raised by a more generous tax treatment of R\&D? They show that it can be quite a cost effective way of raising productivity growth.

\footnotetext{
${ }^{33}$ For example, Nelson and Phelps (1966), Benhabib and Spiegel (1994)

${ }^{34}$ See Sienesi and Van Reenen (2001) for a survey.

${ }^{35}$ Foreign direct investment is also thought to be a key instrument in spreading new technologies (either through competition or more directly, by examples of best practice). Yet the data on this is worse than the other factors and so far, at least, the empirical evidence unconvincing. See Griffith and Simpson (2001) for the latest evidence.
} 
Nevertheless many questions remain over implementation. In particular, given the inelastic supply of R\&D workers the first order effect may be to drive up the salaries of highly skilled R\&D workers (Gooslby, 2000). In the longer run this should have the desired effect of attracting more people into the R\&D sector, but in the short run it will tend to increase (modestly) the degree of inequality. A better approach may be to alleviate the supply problem directly by expanding the supply of highly skilled workers.

\section{VI.2 Human Capital Policy: Invest in basic skills}

The UK educational system does very well for the top end of the ability distribution but very poorly at the bottom. Elite science is traditionally strong (see Figure 7). The UK punches above its weight in terms of papers and citations, being quite close to the US on a per capita basis.

\section{[Figure 7]}

On the other hand, the UK is appalling on most measures of basic skills as the Moser Report, amongst others, has pointed out. The UK has a similar level of functional illiteracy to European countries who have only recently become wealthy (Ireland, Portugal and Greece). Although the US also performs poorly this is mainly to do with the high level of immigration into the US from non-English speaking countries (e.g. Mexico).

There are several advantages of an aggressive policy on human capital accumulation. First, more skills will increase labour productivity for conventional reasons. Second, more skilled workers are complements with new technologies (as discussed in section V) so it should be easier to implement ICTs. Thirdly, the evidence in Griffith et al (2000) suggests there should be an impact on technology transfer and innovation. Some of this may come from the adoption of innovative organisational changes (see Caroli and Van Reenen, 2001). Finally there is the important "double whammy" of improving equity as well as efficiency. If the emphasis is on basic skills then this will tend to lower the degree of inequality as skill acquisition is focused on those most in danger of slipping behind. There could be both increased productivity and an expanded circle of winners.

The government has made a start on expanding basic skills through pre-school initiatives (Surestart), primary school (literacy and numeracy hours), a more rigorous inspection regime (OFSTED) and financial incentives to stay on between 16-18 (educational maintenance allowance). There has been less emphasis on secondary schools. All of these policies, however, no matter how successful they turn out to be will only affect the flow of people entering the labour market. The critical issue is how to deal with the stock of people with poor basic skills (the $20 \%$ functionally illiterate of figure 8). The only really feasible way to reach these groups is likely to be through the benefit system as low skilled people come into frequent contact with the welfare state. The New Deal policy, for example, offers a way of identifying those in need of basic skills training and there needs to be a more systematic and concerted effort to raise their skills. This will have to combine a mix of incentives and careful 
mentoring. A tough policy may have to include benefit sanctions for those who refuse to participate on learning courses.

At the top end of the educational ladder are the universities. The large and growing private return to a university education (see section IV above) suggests that taxpayers' money should not be focused on higher general subsidies to students. The direction of movement should be increasingly towards loans based system where government helps to relax the financial constraints that some low-income families may face. Universities do have a dual function, however, in supplying education and stimulating basic research. They are often at the centre of high tech clusters, such as around the University of Cambridge. This implies that an increased rate of subsidy to research work in universities is a better targeted way of using resources that general subsidies to universities. This basic R\&D is likely to create bigger spillovers than the R\&D tax credit schemes going to private industry discussed above.

\section{VI.3 Competition Policy: Strengthened not weakened}

One view of the competition rules is that they should wither away in the new economy. Critics argue that they are unnecessary (the market will correct itself) and impossible to fulfil (the change is too rapid for a competition authority to make timely decisions). On the "competition policy is unnecessary" argument some of the outlandish claims that the Internet would remove all frictions and usher in an era of perfect competition have been discarded in section III. But the Schumpeterian argument that competition to win a race for a new technology abolishes the need for regulation is also flawed. It is true that there is likely to be an increase in the number of firms enjoying high market shares in the new economy. One reason is that the increased importance of R\&D means more intellectual property protection and associated monopoly power as a reward for innovation. Another reason is the importance of network externalities. These are associated with the fact that the more people who use a product (e.g. a telephone network, a computer operating system, an internet site) the more valuable it becomes. Converging on a standard has huge benefits and once established, the company who produces the standard is in a powerful position to dominate the market (e.g. Microsoft). Both of these factors give new economy industries a "winner takes all" flavour

Market dominance is not welfare destroying per se, but dominant firms have the ability and generally the incentive to behave in anti-competitive ways. For example, incumbent monopolists may have strong abilities to stifle the innovation of rivals. A dominant platform in one technology may enable a powerful firm to leverage into other industries and prevent competition. The Microsoft case hinges on exactly this point $^{36}$. In the browser wars example, the U.S. government claimed that Microsoft deliberately attempted to kill the competitive threat from a new entrant (Netscape) through discriminating against hardware producers who dealt with Netscape and by bundling its own web browser (Internet Explorer) free with the ubiquitous Windows operating system ${ }^{37}$.

\footnotetext{
${ }^{36}$ Fisher (2000)

${ }^{37}$ The recent decision in the Court of Appeal of U.S. vs. Microsoft vacated the remedy imposed by the District Court on Microsoft but upheld the finding of fact that Microsoft had indeed abused its position as a monopolist of PC operating systems to drive out competitors in other markets.
} 
Abuses of monopoly power can and do take place in the new economy. Recent microeconometric work reinforces the message that although theorists may argue over details, empirical evidence demonstrates that product market competition generally spurs innovation $^{38}$. These factors suggest that rather than diminishing competition policy will become more important.

The problem, however, is that the capacity of the anti-trust authorities to deal with competition issues may be limited. This is partly due to complexity. The technological issues are genuinely harder than old economy industries and they change rapidly due to innovation. The experts who can be drawn upon are not disinterested parties and the government's financial resources mean that its own in-house expertise will not be great. Furthermore, these high tech markets are often global which requires cross border co-operation with anti-trust authorities in many countries.

The current government has put effort in strengthening the competition regime. The 1998 Competition Act and the de-politicisation of merger controls are steps in the right direction. Reductions in the degree of protectionism and integration of markets at the European level are also vital. Yet this seems an area where the ability of governments to act effectively is diminishing just as the importance of their actions are increasing (Posner, 2000).

\section{VI.4 Industrial Policy: The example of pharmaceuticals}

Industrial policy in the new economy is about the management of change, not the attempt to pick winners. Many high tech industries interact with the public sector in a myriad of ways - for example through regulation of communications firms, though public purchasing, through partnerships in service delivery and through a thousand more subtle and unintended ways. Modern industrial policy attempts to ensure that the public sector takes a joined up approach to these regulations and does not stifle innovation. The approach needs to be specific to each sector ${ }^{39}$. Particular care should be taken over those industries where the UK appears to have some type of comparative advantage.

The bio-pharmaceutical industry is an interesting example of a successful high tech industry. About a quarter of all UK R\&D is in this sector. This is a greater concentration than any other major country and is suggestive of some sort of comparative advantage in research in this sector. Two of the world's leading firms Glaxo-Smithkline and Astra-Zeneca are based in the UK. The fast-growing biotech industry is stronger in the UK than in any other European country (although Germany has recently had a strong performance).

The reasons for this success are complex. A key influence is the link to a strong academic science base. Analyses of the specialization profiles based on citations reveal a UK comparative advantage in biology and clinical medicine ${ }^{40}$. Secondly, the

\footnotetext{
${ }^{38}$ For example, Blundell, Griffith and Van Reenen (1999).

${ }^{39}$ As one would expect, Griffith, Redding and Van Reenen (2000) find that the drivers of productivity (frontier, R\&D and human capital) have different effects in different industries.

${ }^{40}$ Nickell and Van Reenen (2001) Table 3.8.
} 
industry has long been open to extensive foreign direct investment and competition. Third, there is an absence of negatives affecting other manufacturing industries (e.g. the car industry's poor labour relations and the attempts to create ill-fated "national champions" in the 1970s). Most interestingly, however, is the role of smart government regulation. The UK drug licensing authority was one of the first (1967) to require an efficacy as well as a safety test. This ruled out the strategy of producing low quality "me too" drugs that the Italian and Japanese industry has followed. Furthermore, the system of price and profits regulation ${ }^{41}$ has been voluntary, stable and allowed a reasonable rate of return on R\&D. Obviously this was more important in the days when a significant proportion of sales were made in the UK, but it gave UK industry an important advantage at a crucial stage of industry evolution.

The lesson from the industry is not that all regulation is harmful for innovation ${ }^{42}$. Some regulation is undoubtedly necessary in an industry characterised by extremes of asymmetric information and public procurement (through the NHS). Rather it is that regulation has to evolve is an intelligent way to fit the facts of a particular industry. The British industry faces a number of regulatory challenges. For example, the allowable rate of return for drugs sold to the NHS is undermined by parallel imports from other European countries (such as Greece and Portugal) that regulate for extremely low prices. Re-imbursement policies in the NHS actually encourage this. Some solution to this problem is necessary at the EU level in order to protect the returns to pharmaceutical R\&D. In 1999 the UK government set up a cross government taskforce to work with the industry to find ways to improve the policy framework to foster the competitiveness of the industry and this may be a good model forward for creatively seeking solutions to industry-specific problems ${ }^{43}$.

\section{Conclusions}

I have argued that it is premature to be reading the last rites over the body of the new economy. The acceleration in U.S. productivity growth in the last five years of the Twentieth Century is well documented and the strongest evidence of something "new" in the economic world.

An economist by the name of Karl Marx was a dedicated student of the physiology of the new economy of his day. Unlike the famous passage in the Communist Manifesto, however, "all that is solid" does not "melt into air". The rules and tools of the old economy can be used to map out some of the contours of the new.

I have argued that is much that is not so new about the new economy. At least three things were emphasised. First, key new economy features are a deepening of preexisting trends - the importance of information and communication technologies, of human capital innovation and globalisation. Secondly, one tool designed to track the old economy, that of growth accounting, was be fruitfully used in section III to show how about two-thirds of the recent acceleration in US productivity growth was linked to increased accumulation of ICTs (one third) and faster technical change in the

\footnotetext{
${ }^{41}$ The Pharmaceutical Price Regulation Scheme (PPRS) is analysed in detail in Bloom and Van Reenen (1998)

${ }^{42}$ McKinsey Global Institute (1998) comes dangerously close to asserting this in places.

43 The Pharmaceutical Industry Competitiveness Taskforce, www.doh.gov.uk/pictf/index.html
} 
computer sector (one third). Thirdly, an analysis of MFP growth since the mid 1970s offered a framework for thinking through the policy framework to boost UK productivity. There is no need to discard Samuelson just yet, let alone Smith, Schumpeter or Ricardo.

Some specific policies were sketched. I believe that boosting R\&D and human capital will have major effects on the wealth of UK both in terms of pushing the frontier out and helping us catch up. Competition and industrial policies are also important. Whatever policies are chosen, however, the primary problem is how to take advantage of the prospect of productivity increases without stimulating further increases in inequality. There is still a centrifugal force pushing up the fortunes of the skilled. The gravest danger to the new economy is that the less able and unlucky feel they have nothing to gain from the "knowledge society". Their rejection of it will both be a moral disaster and lead to an erosion of the potential benefits of new technology. 


\section{References}

Aghion, P. and Howitt, P. (1992) "A model of growth through creative destruction" Econometrica 60(2), 323-51

Bailey, J. (1998) "Intermediation and electronic markets: Aggregation and pricing in internet commerce" PhD thesis, Department of electrical engineering and computer science MIT, May 20th

Bell, B., Blundell, R. and Van Reenen, J. (1999) 'Getting the unemployed back to work: the role of wage subsidies' IFS Working Paper 99/07 International Tax and Public Finance, 6, 339-360

Benhabib, J. and Spiegel, M. (1994) "The role of human capital in economic development: evidence from aggregate cross-country data" Journal of Monetary Economics, 34, 143-73

Blank,R. and Card,D. (2000) Finding Jobs: Work and Welfare Reform New York: Russell Sage Foundation

Bloom, N., Griffith,R. and Van Reenen, J. (2001) "Do R\&D Tax Credits Work?" Forthcoming Journal of Public Economics

Bloom, N. and Van Reenen, J. (1998) "Pharmaceutical Regulation in the UK: Where do we go from here?" Fiscal Studies 19, 4, 347-374

Blundell, R. Card, D. and Freeman, R. (2001) Seeking a Premier League Economy, Forthcoming, Chicago: University of Chicago Press

Blundell, R., Griffith, R. and Van Reenen, J. (1999) "Market Structure and Innovation: Evidence from British Manufacturing Firms" Review of Economic Studies $66(3), 228,529-554$

Blundell, R. and Preston, I. (1998) “Consumption and Income Inequality" Quarterly Journal of Economics , 113, 603-640

Bond, S. and Cummins, J. (2000) "The Stock Exchange and Investment in the New Economy: Some tangible facts and intangible fictions" Brookings Papers on Economic Actvivity 1:2000, 61-114

Bond, S. and Jenkinson, T. "The Assessment: Investment performance and policy" Oxford Review of Economic Policy, 12, 2, 1-29

Bond, S. and Van Reenen, J. (2000) "Microeconometric models of investment and employment" (with Steve Bond) forthcoming in Handbook of Econometrics Volume $I V$ edited by Jim Heckman and E. Leamer 
Bresnahan, T., Stern, S. and Trajtenberg, M. (1997) "Market segmentation and the sources of rents from innovation: personal computers in the late 1980s" $R A N D$ Journal of Economics 28, 0, S17-S44

Bresnahan, T., Brnjolfsson, E. and Hitt, L. (2001) "IT, workplace organization and the demand for skilled workers: A firm level analysis" forthcoming Quarterly Journal of Economics

Brookes, M. and Wahhaj, Z. (2000) "The Shocking effects of B2B" Goldman Sachs Global Economics Papers No. 37

Brynjolfsson, E. and Smith, M. (2000) "Frictionless Commerce? A comparison of internet and conventional retailers" Management Science, 46, 4, 563-585

Brynjolfsson, E. and Hitt, L. (2000) "Beyond computation: Information technology, organizational transformation and business performance" Journal of Economic Perspectives, 14, 4, 23-48

Card, D. and Lemieux,T. (2000) "Can falling supply explain the rising return to college for younger men? A cohort based analysis" NBER Working Paper No. 7655

Caroli, E. and Van Reenen, J. (2001) "Organisational Change and Human Capital: Evidence from British and French enterprises in the 1980s and 1990s" IFS Working Paper W99/23 forthcoming Quarterly Journal of Economics

Chennells, L. and Van Reenen, J. (1997) “Technical change and earnings in British establishments" Economica 64, 587-604

Chennells, L. and Van Reenen, J. (2001) 'The effects of technical change on skills, wages and employment: A Survey of the Micro-econometric evidence' in Greenan, N. and Mairesse, J. (eds) The Economic Impact of Information and Communications Technologies MIT Press

Cohen, W. and Levinthal, D. (1989) "Innovation and Learning: the Two faces of R\&D” Economic Journal, 99, 569-96

Crafts, N. and O’Mahony, M. (2001) “A Perspective on UK Productivity Performance", Fiscal Studies

David, P. (1990) "The Dynamo and the computer: A Historical perspective on the modern productivity paradox" American Economic Review 1:2, 355-61

Desjonqueres, T., Machin,S. and Van Reenen,J. (1999) "Another Nail in the Coffin? Or can the trade based explanation of changing skill structures be resurrected?" Scandinavian Journal of Economics, 101(4), 533-554

Department of Trade and Industry (2000) Closing the Digital Divide: A Report by Policy Action Team 13, March

Fisher, F. (2000) "Microsoft, Monopoly Power and Leveraging" Massachusetts Institute of Technology mimeo 
Gordon, R. (2001) "Does the new economy measure up to the great inventions of the past" Journal of Economic Perspectives , 14, 4, 48-74

Goolsbee, A. (1998) "Does R\&D Policy Primarily Benefit Scientists and Engineers?" American Economic Review 88(2), 298 - 302.

Goolsbee, A. (2000) "Does the internet make markets more competitive? Evidence from the life insurance industry" NBER Working Paper No. 7996

Gosling, A. and Machin, S. (1995) "Trade unions and the dispersion of earnings in British establishments" Oxford Bulletin of Economics and Statistics, 57, 167-84

Gosling, A., Machin, S. and Meghir, C. (2000) "The changing distribution of male wages in the UK" Review of Economic Studies, 67(4), 233

Griffith, R., Redding, S. and Van Reenen, J. (2000) "Mapping the Two Faces of R\&D: Productivity Growth in a panel of OECD industries" CEPR Discussion Paper 2457

Griffith, R., Redding, S. and Van Reenen, J. (2001) "Measuring the cost effectiveness of the R\&D tax credit" Fiscal Studies

Griffith, R. and Simpson, H. (1998) Productivity and the Role of Government, IFS Commentary No. C73, November

Griffith, R. and Simpson, H. (2001) "Did Boskin spoil the game? Foreign Direct Investment and Productivity in the UK" IFS mimeo

Griliches (1994) "Productivity, R\&D and the data constraint" American Economic Review, 84, 1, 1-23

Griliches (1996) "The Discovery of the Residual: A Historical Note" Journal of Economic Literature, Vol. 34, No. 3. 1324-1330.

Hall, R. (1999) “The Stock market and capital accumulation" NBER Working Paper No. 7180

Hall, B. and Van Reenen, J. (1999) 'Fiscal Incentives for R\&D: A New Review of the Evidence' NBER Working Paper 7098

HM Treasury (2000) Productivity in the UK: The Evidence and the Government's Approach November.

Ip, Gregg (2000) “Market on a high wire” Wall Street Journal Jan 18

Jorgenson, D. (2001) "Information Technology and the U.S. Economy" American Economic Review, 91, 1, 1-32 
Jorgensen, D. and Stiroh,K. (2000) "Raising the speed limit: US Economic Growth in the information age" Brookings Papers on Economic Activity, 31:1, 125-211

Kneller,R. and Young, G. (2000) "The New British Economy” National Institute Economic Review 177, July, 76-84

Kortum, S. and Lerner, J. (1998) "Stronger Protection or technological revolution: What is behind the recent surge in patenting?" Carnegie-Rochester Conference Series on Public Policy, 48, 247-304

Krueger, A. "How computers have changed the wage structure" Quarterly Journal of Economics, 108, 1, 33-60

Layard, R., Nickell, S. and Jackman, R (1991) Unemployment: Macroeconomic Performance and the Labour Market, Oxford: Oxford University Press

Leadbetter, C. (2000) Living on thin Air, London: Viking

Lee, H.G. (1997) "Do electronic marketplaces lower the price of goods?" Communications of the ACM 41(1), 73-80

Machin, S. and Van Reenen, J. (1998) "Technology and changes in the skill structure: Evidence from seven OECD countries" Quarterly Journal of Economics CXI, 113, $1215-44$

McKinsey Global Institute (1998) Driving Productivity Productivity Growth in the UK Economy

Menezes-Filho, N., Ulph, D. and Van Reenen,J. (1998) "R\&D and Union Bargaining: Evidence from British Companies and Establishments" Industrial and Labor Relations Review (1998) Vol. 52, No. 1, 45-63

Nelson, R. and Phelps, E. (1966) "Investment in humans, technological diffusion and economic growth" American Economic Review 69-75

Nickell, S., Jones T. and Quintini,G. (2000) “A picture of job insecurity facing British men" The Labour Market Consequences of Technical and Structural Change Discussion Paper Series No. 48, forthcoming Economic Journal

Nickell, S. and Van Reenen, J. (2001) "Technological Innovation and economic performance in the United Kingdom" Centre for Economic Performance Discussion Paper No. 488

Nordaus, W. (2001) "Productivity Growth and the New Economy" NBER Working Paper 8097

Oliner, S. and Sichel,D. (2000) "The resurgence of Growth in the late 1990s: Is information technology the story?" Journal of Economic Perspectives , 14, 4, 13-22 
O’Mahony, M. (1999) Britain's Productivity Performance 1959-1996: an international perspective, London: National Institute of Economic and Social Research

Oulton, N. (2001) "ICT and Productivity Growth in the UK" mimeo Bank of England, April

Pencavel, J. (2001) “The surprising retreat of Trade Union Britain” Stanford University mimeo

Posner, R. (2000) "Anti-trust in the New Economy" John M. Ohlin Law and Economics Working Paper No. 106

Sichel, D. (2001) "Information Technology and Economic Growth in the U.S.: An Update and a look ahead" Presentation to the Bank of England, May.

Sianesi, B. and Van Reenen (2001) 'Education and Economic Growth: A Review of the literature' (with B. Sianesi) Centre for Economics of Education Discussion Paper No. 3

Shiller,R. (2000) Irrational Exuberance Princeton: Princeton University Press

Solow,R. (1957) "Technical Change and the Aggregate Production Function" Review of Economics and Statistics 39(3) 312-320

Solow, R. (1987) “We'd better watch out” New York Times Book Review July 12, 36

Van Reenen, J. (1997) “Why Has Britain had slower R\&D growth?” Research Policy 26, 493-507

Van Reenen, J. (2001) "No More Skivvy schemes? Active Labour Market Policies and the British New Deal for Young Unemployed in Context" in Blundell, R. Card, D. and Freeman, R. (2001) Seeking a Premier League Economy, Forthcoming, Chicago: University of Chicago Press

Wadhwani, S. (2000) "Monetary Challenges in a new economy" HSBC Global Investment Seminar, October, www.bankofengland.co.uk/speeches/speech103.pdf

Walton, D. and Broadbent, B. (2000) "Mismeasuring the Economy" Goldman Sachs UK Weekly Analyst 27.10.00

Wood, A. (1994) North-South Trade, Employment and Inequality, Changing Fortunes in a skill-driven world, Oxford: Clarendon Press 
Figure 1 Contributions to U.S. output Growth

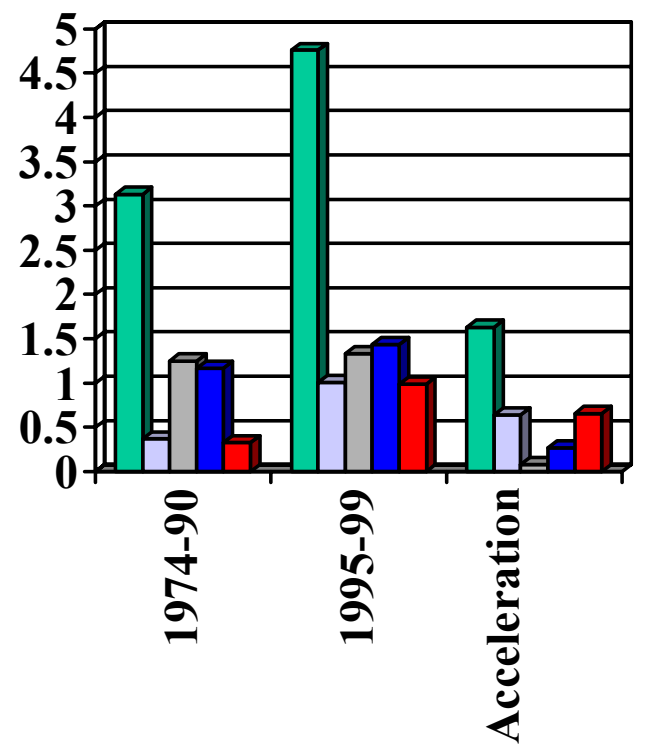

$\square$ Growth of output

$\square$ ICT

$\square$ other capital

Labour Services

Multi-factor

productivity (MFP)

Source: Jorgenson and Stiroh (2000) 
Figure 2: Rapid falls in computer prices (log points)

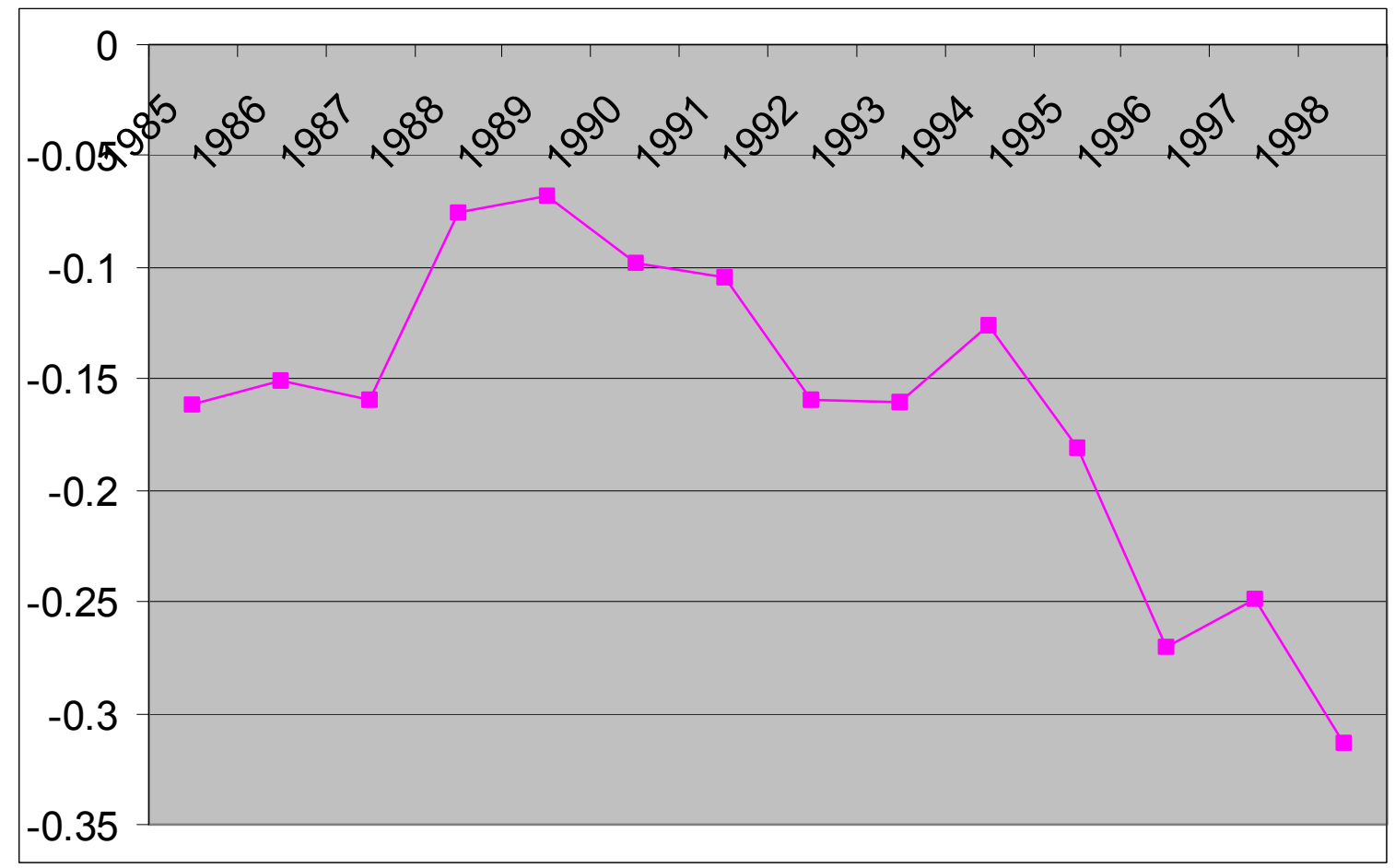

Source: Jorgenson and Stiroh, 2000 


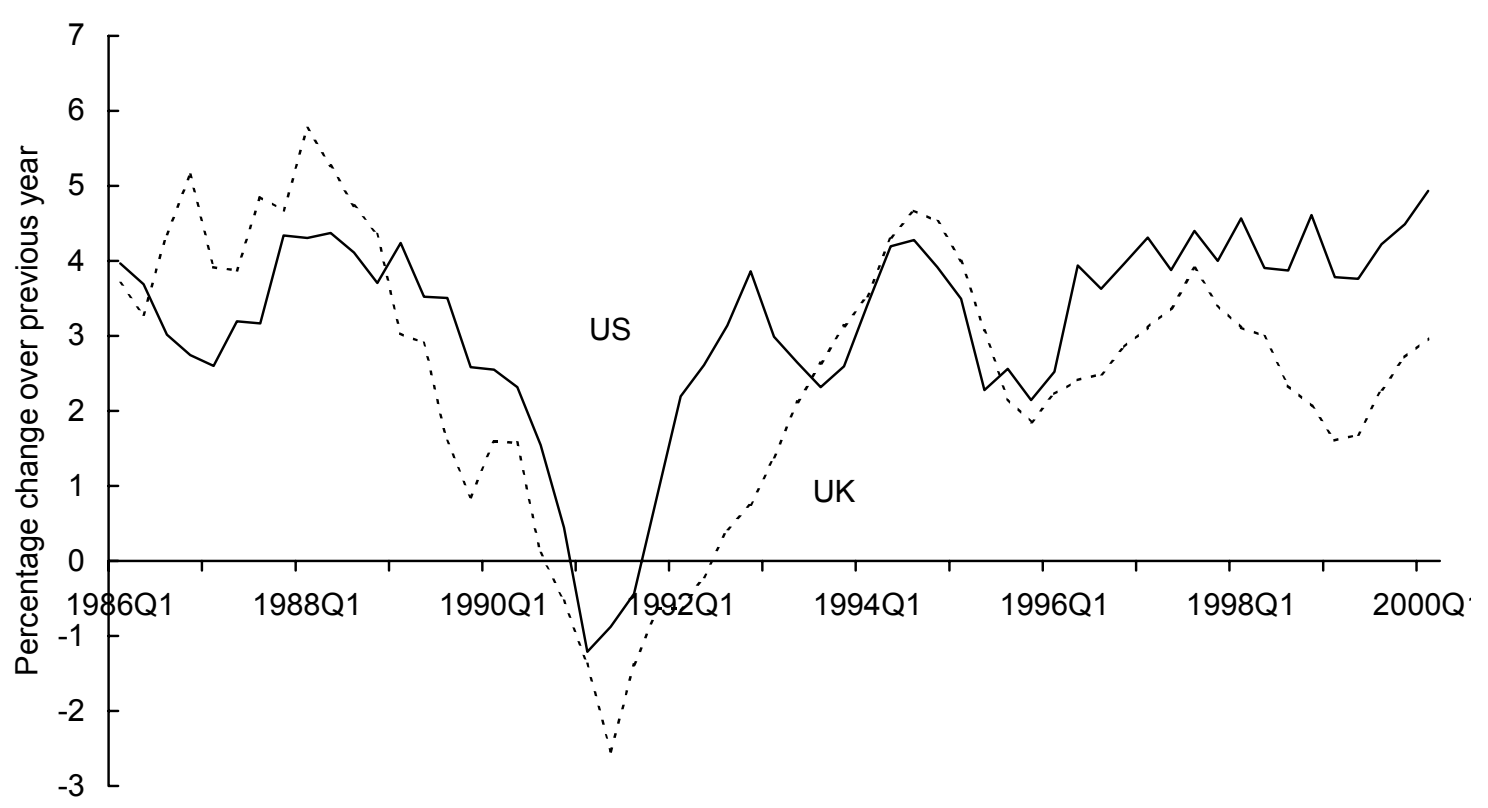

Source: Kneller and Young, 2001 
Figure 4: Business Labour Productivity in the UK and US using US ICT deflator for both countries

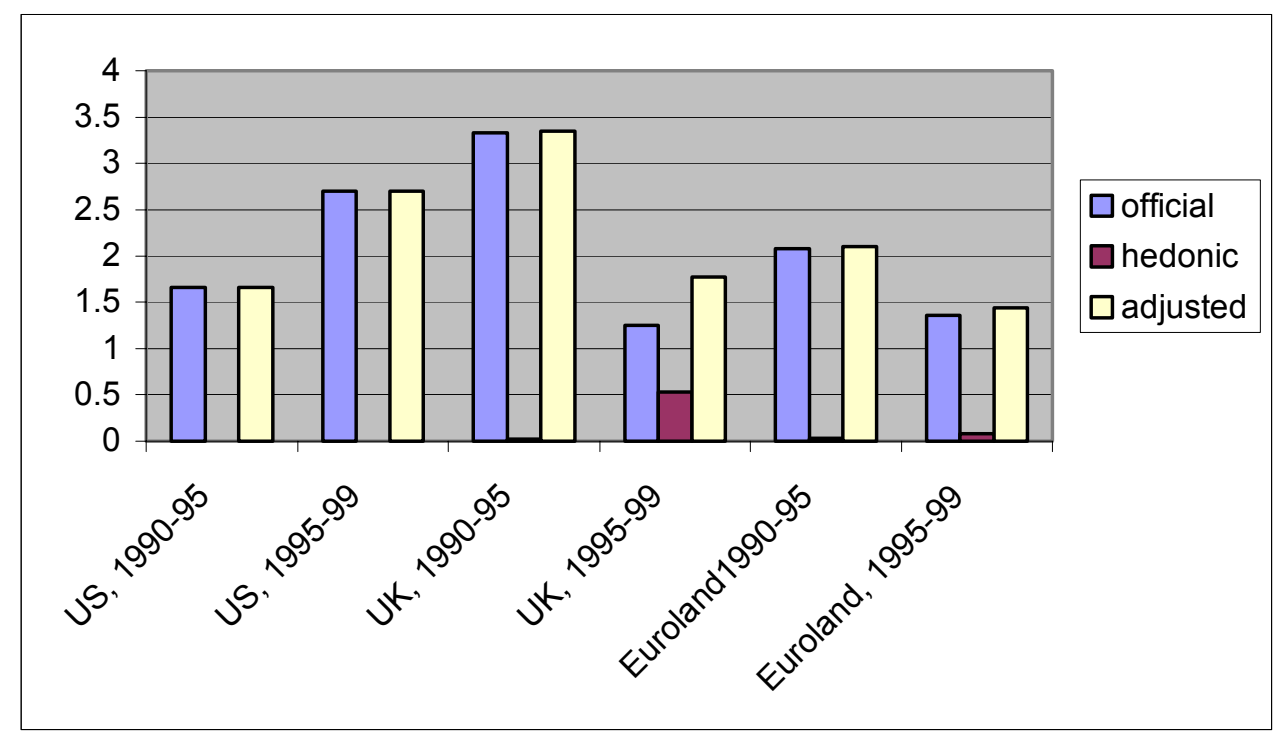

Source: Walton and Broadbent (2000) 
Figure 5: Internet hosts per 1,000 population (1999)

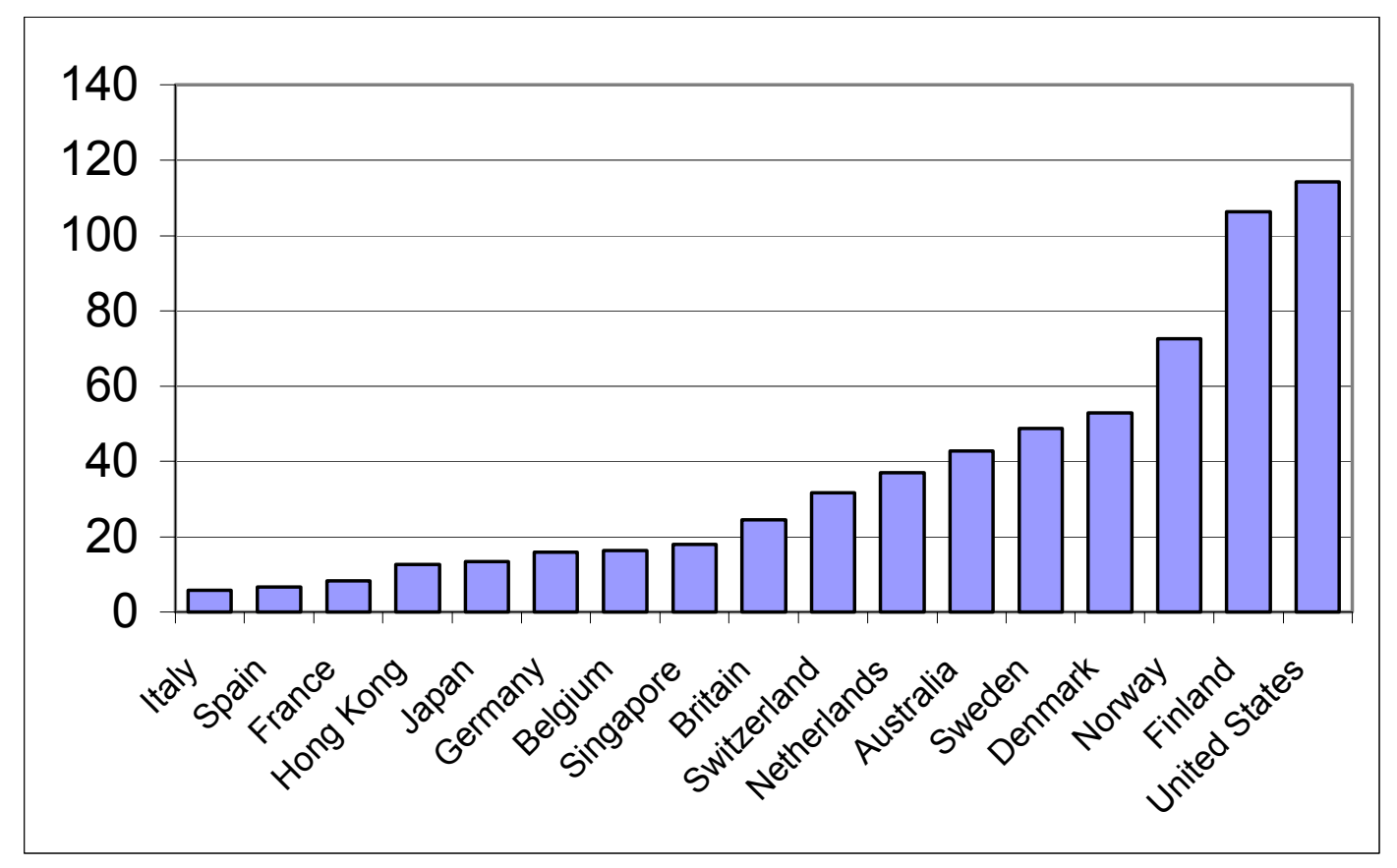

Source: World Bank (2000) 
Figure 6: Increase in UK male wage inequality, 1966-1996

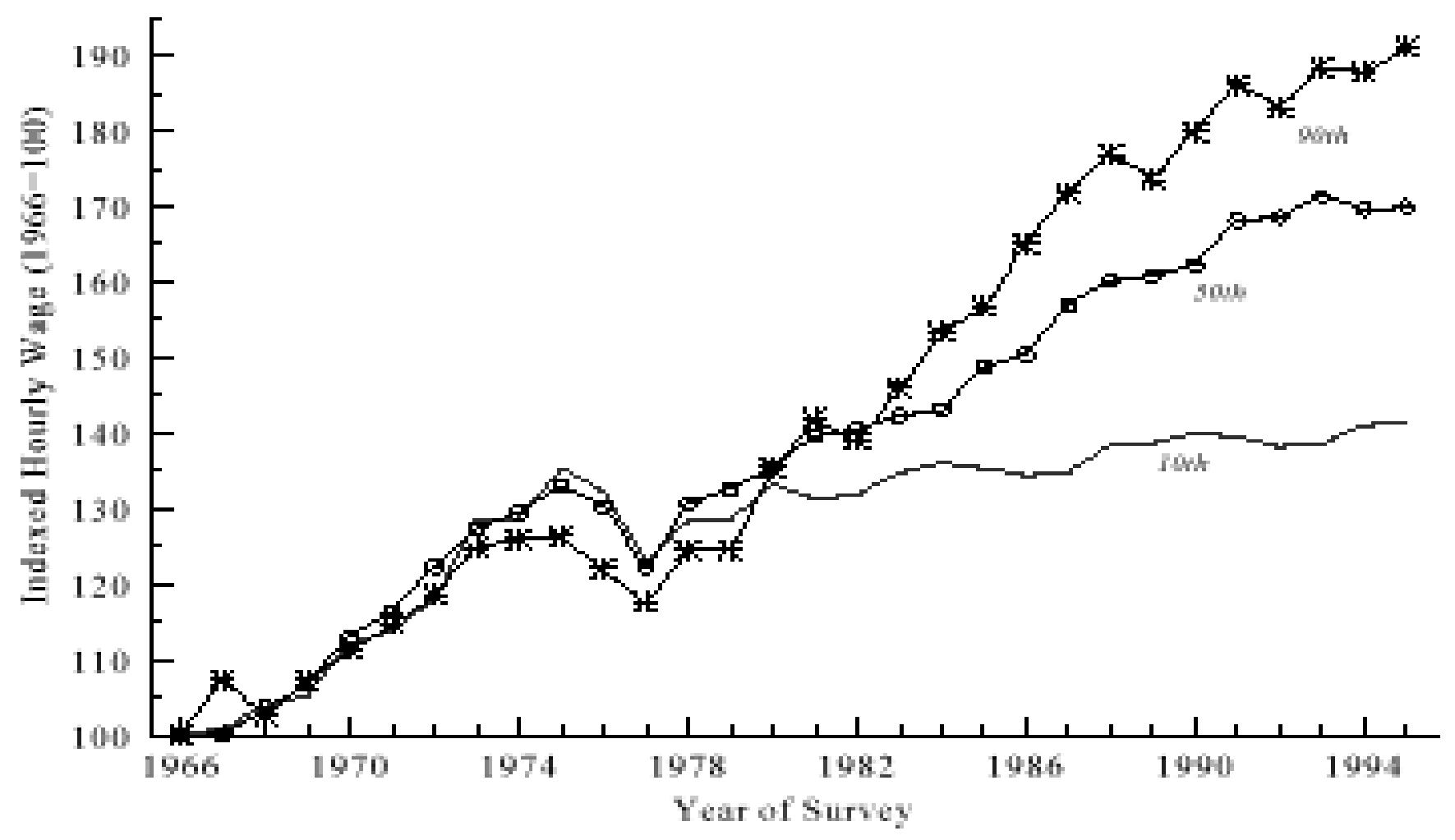

Source: Gosling, Machin and Meghir (1999) 
Figure 7 : Indices of Science Base, 1981-94 average

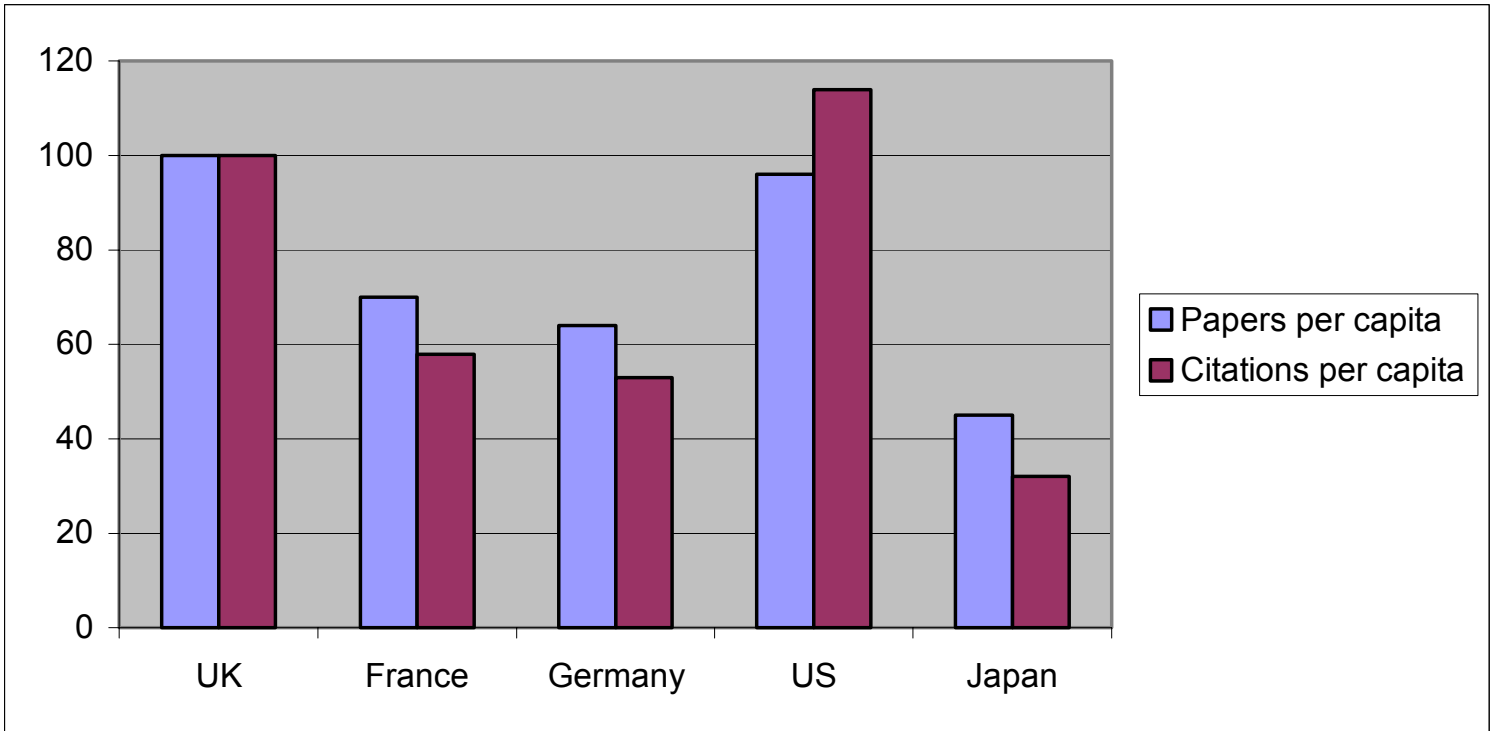

Source: UK Office of Science and Technology 
Figure 8: Functionally Illiterate (\% aged 16-65), 1995

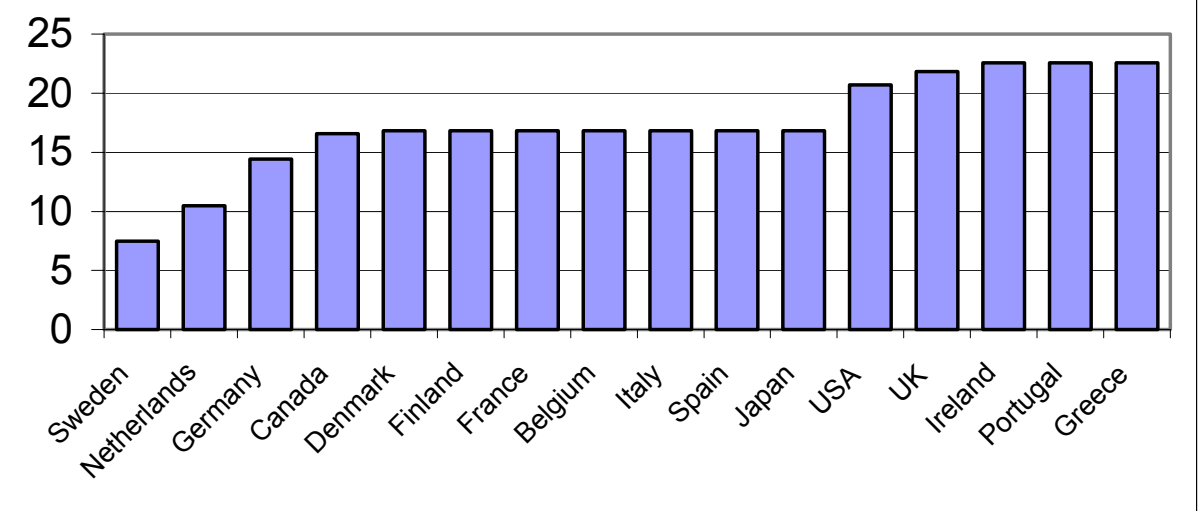

Source: UN Human Development Report 